\title{
A Good Black Music Story? Black American Stars in Australian Musical Entertainment Before 'Jazz'
}

\section{John Whiteoak}

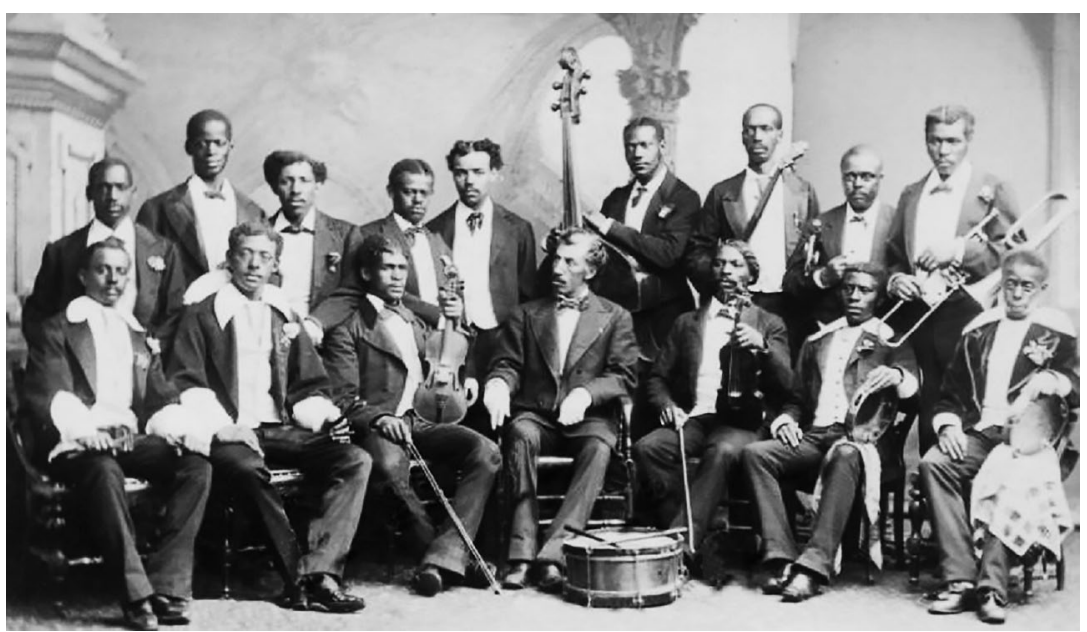

Figure 3.1: Charles B. Hicks' Original Georgia Minstrels, 1885

Source: Australian Variety Theatre Archive: Popular Culture Entertainment: 1850-1930, ozvta.com/troupes-g-1/. 
History once stated that thick-lipped musicians were no good on brass instruments, especially the cornet. Well, that theory was killed when these coloured stars got on the job. (Critic, 1917)

A major problem in jazz-related research and writing has always been the use of terms like 'black music' or 'jazz' as what would be classed as 'master signifiers' according to the widely influential theories of psychoanalyst and theorist Jacques Lacan. Master signifiers are words like 'appropriate', which are used as 'placeholders' for things we do not fully understand or for which we lack satisfactory definitions. Lacan's theory refers to three categories of meaning associated with words: 'the symbolic' (what is signified), 'the imaginary' (what is imagined) and 'the real'. ${ }^{1}$ The theory suggests that 'the real' can never be precisely known because of its integral interrelationship to what is both imagined and signified by a word. ${ }^{2}$ Lacan's theories are controversial, sometimes contradictory and often misinterpreted, and were conceived specifically for psychoanalysis. Yet the simple notion or truism inherent in his notion of the master signifierthat particular words are used as placeholders for meanings that actually fall somewhere between what is signified and what is imagined by that word — can also be usefully applied to a relatively non-theoretical historical musicological analysis such as that presented below.

In Lying Up a Nation: Race and Black Music, ethnomusicologist and black music theorist Ronald Radano (2003) views the term 'black music' as a placeholder, but he uses 'lying' in the positive sense of black music being a 'good story' or good myth. Along with exhaustive critique of theoretical debate concerning black music, Radano (2003, p. 33) examines, through numerous early primary sources, the extent to which this 'good story' was constructed and essentialised by early white American commentators and their writings and representations (such as the blackface minstrel show) in 'white-over-black narration'. He proposes an alternative story based on a deep critique of the sources that have shaped the 'good black music story'. This story would be less of a caricature than, say, the controversial 2001 Ken Burns documentary Jazz (Pond, 2003, pp. 11-45): more nuanced, complex, interracial and all the more convincing, richer and dignifying for seeking 'musical truths among the gossamer of tall tales' (Radano, 2003 , p. 42). It would be grounded in the understanding that early black

1 For an accessible overview of Lacan's psychoanalytic theory, see Bailly (2009).

2 The 'master signifier' analogy was inspired by a paper presented by composer and semiotics/ music theorist Thomas Reiner (2015). See also Bailly (2009, pp. 61-64). 
music history is not fully knowable in the same sense that Lacan's 'the real' is not fully knowable, but 'nonetheless voices a truth about life and nation' (Radano, 2003, p. 25). This study does not critique or apply Radano's many-stranded analyses and theories about the US's good black music story. Instead, it asks whether pre-jazz Australia could possibly be a part of this story, given that numerous African-American singers, dancers and instrumentalists performed in Australia before Australia's Jazz Age (c. 1918-28). It focuses on an especially important aspect of this question, primarily from a basic musicological perspective. ${ }^{3}$ Given that the term 'jazz' was meaningless to the Australian public before the earliest overseas reports in late 1917, is it possible that the band and orchestra music associated with particular black minstrel shows that toured Australia before this time was an incipient form of black jazz?

'Early jazz' historiography has tended to emphasise the 'pure' folk roots of jazz and blues while turning a blind eye to the role of mainstream 'commercial' music-making of black band and orchestra musicians in early jazz development (Gennari, 2006, p. 121). The absence of early sound recordings of New Orleans jazz and vernacular blues greatly facilitated myth-making about the origins of jazz and blues. However, revision of the early black music story has in fact commenced with the work of scholars such as Lotz (1997), Abbott and Seroff (2002, 2007), Brooks (2004), Gushee (2005), Berresford (2010) and others. Berresford (2010, p. 7) points out that 'only recently has the pivotal role of touring minstrel shows and circus sideshow bands in the formative period of jazz and blues evolution been researched in any depth'. He further states that what these researchers are revealing:

Flies in the face of the romantic notion of early jazzmen being gifted musical illiterates, pouring forth a stream of endless improvised melody, oblivious to the rules and conventions of 'proper' music. In reality, musicians groomed in the world of the tent show and the circus were those most in demand in other areas of musical activity. Orchestra leaders ... valued highly the circus musicians' sight-reading and improvisational abilities, coupled with their ability to 'follow' a stage performer in their routine'. (pp. 28-29)

3 The chapter is significantly indebted to Waterhouse (1991) and the Australia-related content of Abbott and Seroff (2002). 
Steven Lewis (2012) argues similarly in his thesis, "Untamed Music": Early Jazz in Vaudeville', which 'challenge[s] previously held assumptions about ... New Orleans as the sole birthplace of early jazz — and shed[s] light on jazz's place in the broader popular culture landscape of the early 20 th century' (p. 10). He stresses the improvisatory nature of commercial black tent shows and vaudeville music making (Lewis, 2012, pp. 107108). The famous so-called 'Father of the Blues', W. C. Handy (1970), complained about musicians who 'bowed to the authority of the printed note, unlike minstrel musicians who could "fake" and "sell it" (p. 80). Readers of Playing Ad Lib, Improvisatory Music in Australia: 1836-1970 (Whiteoak, 1999) will find many similarities to Berresford and Lewis' observations regarding the improvisatory nature of circus, variety, vaudeville and white and African-American minstrel-show music in Australia before jazz (Whiteoak, 1999, pp. 122-124, 150-152).

\section{'Jazz' in Australia}

Australian jazz history is widely considered to have commenced in June 1918 with the interstate tour of vaudeville act 'Australia's First Jazz Band'. Often cited as the first black jazz band to reach Australia, Sonny Clay's Plantation Orchestra arrived in 1928 as part of the Colored Idea Revue troupe, but was forced to depart following accusations of miscegenation and drugs (Johnson, 2010).

For the sake of later discussion of minstrel band and orchestra music, however, the term 'jazz' should be considered a placeholder for something that has meant, and continues to mean, many different things, according to when, where or who is defining it. For example, in jazz-age Australia, as elsewhere, jazz was used as a verb-'to jazz' or 'jazzing' - to mean embellishing and transforming popular music with African-Americaninflected idioms to make it more rhythmic, colourful, entertaining, amusing, or (to use another master signifier) 'hot' (Whiteoak, 1999, pp. 168-230). Making popular music hot, or jazzing it, involved the improvisatory interpolation of idiomatic 'fills' or 'breaks', novelty sound effects and hot 'participatory discrepancies'-barely perceptible but expressive surface embellishments, ornamentations, timbrel variegations, over-blowing, rhythmic displacements and 'grooves', and other unscored alterations or creative 'noise-making' that essentially defy notation (Keil, 1994, p. 104). However, making popular music hot with idiomatic 
interpolations or alterations was called 'ragging' decades before the Jazz Age (Berlin, 1980, pp. 66-71) and had always been an essential aspect of blackface (white) minstrelsy and later black (African-American) minstrelsy in forms that reached Australia before the Jazz Age (Whiteoak, 1999, pp. 68-230; 2014, pp. 29-35).

In the 1994 article 'Jazzing” and Australia’s First Jazz Band' (Whiteoak, 1994, pp. 279-295), I demonstrate that the observed jazzing or jazz improvisation of this ensemble was largely the ragging of ragtime repertoire. This ragging, or jazzing, was furthermore perceived to be related to the extroverted, unorthodox, noisy and highly comedic music of the 'old-time' minstrel-show orchestras: 'The band reminded one of the old-time $\mathrm{N}$ [egro] minstrel bands. For the most part the members made more noise than music - simply "jazzed" away for all they were worth' (The Advertiser, 1918). ${ }^{4}$ The terms ragging and jazzing remained synonymous in Australia until the early 1920s. A key connection or continuity between the music, dance and acting of the black minstrel artists and ensembles discussed below and the earliest so-called 'jazz' or 'jazzing' in Australia lay very much in the notion of comic distortion or clowning, and in what was misconceived to be musical clowning.

\section{Black Minstrelsy in Australia}

The history of jazz-related music in Australia begins in 1838 when white colonial actor-dancer-musicians in burnt-cork make-up presented improvisatory 'Negro' music and dance acts like 'Jump Jim Crow' or 'Zip Coon' on the popular stage (Waterhouse, 1991, pp. 1-12; Whiteoak, 2014, pp. 29-34). These individual 'blackface' artists were followed a decade later by touring blackface (white) minstrel troupes with earplaying minstrel 'orchestras' (typically) of banjo, fiddle, bones and tambourine, and featuring performance behaviour and improvisatory practices that anticipated those of ragtime and jazz, as documented in Whiteoak (1999, pp. 83-110; 2014, pp. 29-34).

4 See also Whiteoak (2014, p. 46). 
- ear-playing

- head-arrangements

- $\quad$ percussion accompaniment, 'fill', 'breaks', solos and duets and 'imitations' on bones and tambourines

- polyrhythmic body percussion as 'patting juba dance accompaniment'

- syncopation, complex polyrhythm and improvisatory fills and variations on banjo

- 'talking banjo' (musical imitation of spoken replies)

- variations on fiddle, flutina and banjo

- musical burlesque and novelty noise

- improvisatory and extended vocal techniques

- collective improvisatory musical play

- incipient vocal and instrumental 'ragging'

- improvisatory dance.

Figure 3.2: Jazz-antecedent practices in minstrelsy

Source: Whiteoak (1999).

Black American artists were able to enter this field of entertainment after the 1861-65 Civil War, but, to be successful, they had to adopt and adapt the demeaning blackface stereotyping and comic distortion of themselves and their culture. ${ }^{5}$ While white minstrels in burnt-cork make-up were respected for the cleverness of their parody, burlesque or comic distortion of slave plantation performance culture, African-American minstrels were often perceived by colonial Australians as just playing their AfricanAmerican selves - mildly exotic and inherently amusing live exhibits. For example, 'REAL COLORED MEN From the Slave States of America, [who] will Appear in an ENTERTAINMENT, Portraying the peculiarities of Negro Life on the Plantation' (Newcastle Morning Herald and Miners' Advocate, 1876, p. 5-6) or 'Their movements are very fantastic, and they bound from their seats and play their bones and tambourines in attitudes that none but india rubber [sic] men or marionnettes could imitate ... and crack jokes with a gusto seldom witnessed among white men' (South Australian Chronicle and Weekly Mail, 1877, p. 15).

Various all-black minstrel companies, or so-called 'Georgia' companies, with white or African-American managers toured Australia between 1876 and 1914 (see Figure 3.3) and African-American 'jubilee ('Negro spiritual' singing) companies also toured over the same period (and later) with considerable appeal to colonial Christians. The Georgia companies also featured 'Negro spirituals' but often hammed up to amuse their colonial audiences (Abbott and Seroff, 2007, pp. 21-22). The Georgia companies

5 Even then, colonial critics often complained that troupe members were 'piebald' and not uniformly pitch-black like blackface minstrels. 
were also hired for numerous local productions of the immensely popular melodrama, 'Uncle Tom's Cabin', in which they played black roles and presented slave plantation music and dance scenes with jubilee singing, slave field songs, banjo playing and improvisatory so-called 'plantation walk-around' dancing (Waterhouse, 1991, pp. 70-74). By the time the first Georgia minstrels reached Australia, local and touring white minstrel companies were de-emphasising the more jazz-like 'old-time slave plantation' music and dance aspects of their shows. However, this was kept alive as a plantation-life specialty of the black Georgia companies.

- 1876-1877: Sheraden Corbyn's Original Georgia Minstrels

- 1877-1880: Charles B. Hicks Georgia Minstrels

- 1881-1883: Mastodon Colored Minstrels: 60 artists including most of the Original Georgia Minstrels

- 1886-1889: Loudin's Fisk Jubilee Singers

- 1888-1891: Hicks-Sawyer Minstrels

- 1890-1920s: Orpheus McAdoo's Virginia Concert Party and Jubilee Singers (with personnel and name changes)

- June 1899-1900: McAdoo's Georgia Minstrels and Alabama Cakewalkers and Brass Band; Curtis' Afro-American Minstrel Carnival and Brass Band

- December 1912 - December 1913: Hugo's Colored Minstrels

- 1914: Hugo's New Minstrels (included white Australians).

Figure 3.3: Black minstrel and jubilee companies in Australia, 1876-1914 Source: Abbott and Seroff (2007) and Waterhouse (1991).

At the end of the 1880s, the Hicks-Sawyer company introduced the new so-called 'coon-song' and urban-themed 'hot coon' stereotype to Australia. Coon-song became immensely popular but also increasingly depicted urban African-Americans as flashy, gluttonous, gamblingaddicted, ugly, 'uppity', razor-wielding, oversexed and excitingly rhythmic (Whitcomb, 1987, p. 100). In 1899, McAdoo's Georgia Minstrels and Alabama Cakewalkers and Curtis' Afro-American Minstrel Carnival introduced the new 'ragtime' and cakewalk-style minstrelsy to Australia (Whiteoak, 1999, pp. 116-134). Coon-song had become a vehicle for ragtime syncopation and improvisatory vocal ragging and its verse/chorus structure invited 'hot' ragged chorus accompaniment.

While the music and dance of the Georgias was often essentialised by Australian observers as naturally spontaneous, improvisatory and comedic, this perception is even more apparent in the numerous Australasian reviews of touring jubilee singing and jubilee/variety troupes collated in Abbott and Seroff (2002). The authors point out that because Australasian audiences were unfamiliar with the peculiarities and conventions of 
African-American culture', they interpreted improvisatory musical gestures and expressive physical movement as 'comedic' or 'ludicrous, ridiculous, and humorous' (Abbott and Seroff, 2002, pp. 21-22).

Black minstrelsy enriched Australian popular entertainment with the presence and influence of many world-famous stars of African-American minstrel music, dance, comedy and variety. They included Japanese Tommy (Thomas Dilverd), minstrel and minstrelsy entrepreneur Charles Hicks, Billy Wilson, Sam Keenan, Billy Crusoe, Billy Speed, banjo virtuoso Hosea Easton, Charlie Pope, Irving Sales, cakewalkers Charles W. Walker and Ida May, Billy McClain, vocal ragtime and ragging pioneer Ernest Hogan, Billy Brown, Billy Kersands and Eva Taylor of later blues and jazz singing fame. Easton, Pope, Sales, Keenan, Brown and various others remained in Australia after their troupes had broken up or returned to North America; they became very popular in Australian minstrelsyrelated entertainment (Waterhouse, 1991, pp. 93-95).

\section{Minstrel Bands and Orchestras}

The most tantalising feature of the black minstrel companies from a later 'jazz in Australia' perspective is their strikingly costumed black minstrel parade and concert brass bands, which also played for the minstrel show, especially as these were exactly the same type of pre-jazz black ensembles that are exhaustively documented in Abbott and Seroffs (2007) Ragged but Right: Black Traveling Shows, 'Coon Songs,' and the Dark Pathways to Blues and Jazz.

Corbyn's Georgia Minstrels (1876-77) only carried a drum and fife parade band (Launceston Examiner, 1877, p. 3), but the Hicks, Mastodon, Hicks-Sawyer and later black companies carried popular 'brass' (brass and woodwind) parade/concert bands that (with doubling on strings) became minstrel-show orchestras accompanied by the noisy rattling of bones and tambourines. Colonial reviews and advertisements often provide detailed information about the size and instrumentation of the bands, their colourful parade uniforms, who led them, what items they played and even the names of many of the performers. These reviews rarely describe music performance practice or performance behaviour. Thus, circumstantial evidence must be relied on to determine what sorts of idiomatically African-American or other participatory discrepancies, or incipient ragging and jazzing, the musicians might have brought to their music to fulfil the white public's expectations of the 'ludicrous' comic 
musical distortion of the 'happy' and rhythmic musical 'darkie' at play. Did the black bands that reached Australia, for example, feature a mix of untrained ear-playing and trained reading musicians as in legends about the origins of New Orleans jazz?

Such questions become even more important when considering the late 1890 s, when the syncopated ragtime subgenres, cakewalk-march music and coon-song entered minstrel band repertoires. A further problem is uncertainty, in the absence of confirming evidence on record, about the precise nature of the music of New Orleans (or other US locations) that became, retrospectively, known as 'jazz' in the 1910s, or about how this early 'jazz' or 'jazzing' might have differed from black bands playing and enthusiastically embellishing or 'ragging' the new syncopated ragtime subgenres.

An important early example of wind band ragging is the attentiongrabbing circus trombone 'smears', 'glisses' or 'rags' (later called 'jazzes') of cakewalk-march music. Trombone historian Rick Benjamin states that 'dating back to the 1870 s ... white performers in blackface used the trombone as a raucous noisemaker to somehow assist in their "evocations" of plantation life' (cited in Wondrich, 2003, pp. 75-76). Cakewalk-marches are composed and arranged music, but in Stomp and Swerve: American Music Gets Hot, 1843-1924, David Wondrich (2003) demonstrates through musicological analysis of examples, such as Arthur Pryor's 1902 recording of 'Trombone Sneeze: A Humoresque Cakewalk' played by the famous Sousa band, ${ }^{6}$ that even a conservative white wind band could bring surprisingly jazz-like freedom to its performances of this genre (pp. 63-81).

Being parade bands that functioned to attract public attention and patronage from far away to the minstrel show, there is no doubt that minstrel musicians, like circus musicians, could play very loudly. Even when functioning as minstrel orchestras, they were sometimes censured for being sonically overpowering (The Queenslander, 1888, p. 752). There is also an intriguing reference to the Hicks-Sawyer band in a tune-for-tune volume 'battle' with the famous Australian Wirth's Circus band (Wirth, 1925 , p. 45); the ability to play exceptionally loud is central to the murky myth of the early New Orleans trumpeter Buddy Bolden considered by many as the 'Father of Jazz' (Marquis, 2005, p. 70).

6 Hear this at youtube.com/watch?v=P3NU7LGBDcA (accessed 23 March 2016). 
Published Australian observations of the black minstrel band musicians often give the impression that they were well trained and disciplined in music and marching in an era when the modern brass or mixed brass and reeds band was central to Australian public popular entertainment and organised amateur music making (Whiteoak, 2001, pp. 27-48). Therefore, these critics were in a suitable position to compare the quality of the black minstrel bands with the leading Australian amateur, volunteer, circus and other commercial bands of the era:

There are many in Hobart who can remember the Hicks-Sawyer Minstrel Band, which paraded from the Theatre Royal daily decked in darktown rig, and at the head of which was a drum major who skied his staff away up into the heavens, and caught it the same way in various gymnastic shapes. History once stated that thick-lipped musicians were no good on brass instruments, especially the cornet. Well, that theory was killed when these coloured stars got on the job. But eight or nine of them, they fairly shook the town, and their music, well it made lads and lassies leave the counter and workshop it was of such an enticing and gripping character. To say darkies have no soul. The Hick-Sawyer troupe proved [this to be a lie]. (Critic, 1917, p. 6)

Where the names of minstrel company band members are known, it can be shown that many also doubled as star comedians, vocalists, buck and wing dancers, or variety act artists (see Figure 3.4).

- Henderson Smith Leader, solo Bb cornet (and M.D. for the show)

- Jessie E. Smith, solo Bb cornet

- James P. Jones, solo clarinet

- James Harris, first trombone

- Alonzo Edwards, second trombone

- Oscar Lindsay, solo alto horn

- John Brewer, first alto horn (and sketches, cakewalker, buck and wing dancing)

- Pete Woods, baritone horn (other role unknown)

- Edward Tolliver, tuba (and juggler)

- Turner Jones, bass drum (and juggler)

- Frank Poole, snare drum (and sketches)

- Jackson Heard, cymbals (and sketches)

- George Henry, drum major (other role unknown)

- John Pamplin, lightning gun driller (and juggler).

Figure 3.4: The McAdoo Company Brass Band and Orchestra, 1899

Source: Derived from listing of McAdoo Company personnel and their roles in Abbott and Seroff (2002, Appendix 2, p. 464). 
This mirrored the situation of the travelling Australian family circus bands of that period, which necessarily brought skilled professional musicians together with untrained musicians/circus performers (who could not necessarily read music) in contexts requiring improvisatory musical interaction, such as in backing unpredictable variety acts (Whiteoak, 1999, pp. 69-82). Irving Sales, a leading minstrel comedian and coonsong and minstrel dance artist in the 1880s Hicks-Sawyer company, and later star comedian and 'coon-specialist' in Australian vaudeville, was especially recalled by a journalist as having been the slide trombonist in the Hicks-Sawyer street parades (Day, 1917, p. 14). What, if any, flamboyant, attention-grabbing liberties or 'razzamatazz' this gifted black minstrel/comedian/slide trombonist brought to his street-parade playing must remain a matter of speculation.

All brass bands carried by the black minstrel companies featured one or several star instrumentalists to boost the repute of the band and appear as soloists. The 14-member brass band of the 1899-1900 McAdoo Georgia Minstrel and Cakewalkers was led by a very famous conductor and cornet soloist, Professor Henderson Smith, known in America as 'the black Sousa' (Abbott and Seroff, 2002, p. 128). Rival Curtis' Afro-American Minstrel Carnival company featured the 'Famous Kansas City Pickaninny Band', an acclaimed 16-member teenage band led by Professor Nathaniel Clark Smith (Brisbane Courier, 1900, 2), ${ }^{7}$ who is credited with training jazz musicians such as Walter Page, Harlen Leonard, Leroy Maxey and the legendary Wilbur C. Sweatman, who Berresford believes was a member of the Pickaninny Band during its Australasian tour (Berresford, 2010, pp. 21-24). ${ }^{8}$ A program published in Kansas City soon after the Australasian tour bills the Pickaninny Band as presenting 'A Ragtime Concert given in front of the [Grand Opera House] each evening'(Londré, 2007, p. 207), remembering that use of the term 'jazz' in popular music was still more than a decade away.

Both minstrel bands had departed Australasia by May 1901 and, disappointingly, numerous reviews of both companies fail to detail what ragging, participatory discrepancies or other razzamatazz they brought to their music as parade or concert bands playing cakewalk-marches, coonsongs and other early ragtime or cakewalk-era popular music. Similarly,

\footnotetext{
7 See also Abbott and Seroff (2002, pp. 403-409).

8 See a Pickaninny Band image at images.fineartamerica.com/images/artworkimages/mediumlarge/ 1/old-kentucky-the-original-pickaninny-band-1894-r-muirhead-art.jpg (accessed 25 March 2016).
} 
they reveal very little about how, as orchestras, they accompanied black dancing, coon-song and 'rag-time opera' in the dynamic comic-distortion 'mirth factory' context of ragtime minstrelsy.

\section{Some Circumstantial Evidence}

The most common terms used to describe the parade bands' music were 'enlivening', 'spirited' or 'stirring'. For example:

Twenty [black minstrels] turned out with their champion brass band, marching through all the leading streets, and performing various spiritstirring airs in masterly style ... followed by admiring crowds, and all doors, windows, and sidewalks were crowded with astonished spectators. (The Cornwall Chronicle, 1877, p. 2)

By the late 1890s, however, ragging or ragtime improvising (including the trombone 'smears' or 'rags' associated with cakewalk-march music) was already becoming codified in 'how to rag' instructors and notated representations of ragging in Tin Pan Alley scores (Harney, 1897; Whiteoak, 1999, pp. 111-67). In fact, world-famous coon-song ragger, comedian and composer Ernest Hogan, who headed the Curtis company, had produced a massive global coon-song hit in 1896, published with both straight and optional ragged chorus accompaniment. ${ }^{9}$ Novelty or unorthodox noise-making and musical burlesque or clowning had always been part of the comedic appeal of minstrelsy and, in the case of black minstrels, being comedic was perceived by many to be a natural and expected attribute. Minstrelsy had always been a context for improvisatory music practices. Furthermore, among the minstrel musicians were concert soloists with an excess of musical ability, such as clarinettist James P. Jones or solo cornet players Frank Hewett, Charles Bruce, Jessie P. Smith and Henderson Smith, who probably performed cadenzas or variations on the parade band tunes, which they knew by heart. ${ }^{10}$ The Kansas Pickaninny Band leader Nathaniel Clark Smith is a legendary figure in jazz education history; it is likely that famous jazz pioneer Sweatman was in Australia as a band member (Berresford, 2010, p. 24).

9 'All Coons Look Alike to Me: a Darkey Misunderstanding'. 1896. New York: M. Witmark \& Sons.

10 Also argued in Lewis (2012, p. 41). 
Despite the very modest commercial success of these two large black minstrel companies, there is no doubt of their significance in exposing Australian audiences to the new syncopated and improvisatory ragtime music and dance genres and the way they were performed by black artists. ${ }^{11}$ Circumstantial evidence points to the probability that the band and orchestra music was playfully embellished in ways that would be recognised, today, as incipient jazzing.

\section{'T'ain't What You Do (It's the Way That You Do It)'12}

\section{'Real' Ragtime}

The last large-scale black minstrel company to tour Australia, Hugo's Colored Minstrels, arrived in late 1912 led by world-famous minstrel Billy Kersands, and featuring genuine 'old-time minstrelsy' ragtime dancers, a 'Real Ragtime Band' (Daily Herald, 1912a, p. 2) and Leah Clarke, an Amazonian lady 'rag-shouter' who sang 'to beat the band' and got audiences 'jiggin' with her hot interpretations of the latest ragtime hits (The Mail, 1912, p. 3; The Register, 1912, p. 5). During the long but ultimately ill-fated tour, company members were refused accommodation on colour 'taboo' grounds, bashed by racist thugs and ostracised by the gutter press for entertaining white women in a scandal that preceded the infamous 'Colored Idea' scandal by 17 years (Albury Banner and Wodonga Express, 1912, p. 20; Truth, 1912, p. 5).

Clarke's 'singing to beat the band' anticipated the novelty of the two equally Amazonian white 'rag-shouters' who respectively led and competed, volume-wise, with 'Australia's First Jazz Band' six years later (Whiteoak, 1994, p. 289). Descriptions of the Hugo company's breezy music and dance extravaganza finale, called 'Alexander's Ragtime Band' resemble another extravaganza called 'Alexander's Jazz Band', presented in a Sydney revue months before the 1918 Jazz Band. However, the 'Real Ragtime Band' feature is of particular interest from a jazz perspective.

11 However, the degree to which the minstrel musicians were actually, to quote Abbott and Serroff (2002, p. 451), 'asserting an African-American cultural sensibility' in their playing is a far more difficult problem.

12 Common saying in show business and title of a 1939 jazz song by Melvin Oliver and James Young. 
An important clue to the existence of a new, unfamiliar and special quality about this 'real' ragtime band is its highly publicised claim that it would demonstrate to Australians 'how Irving Berlin's "Everybody's Doing It" and "Alexander's Ragtime Band" should be played', or in other words, ragged or otherwise transformed by African Americans into 'real ragtime' (Daily Herald, 1912b, p. 3).

Therefore, we have to momentarily return to Lacan and the word 'real' itself as a placeholder, since there is no certainty about what 'real ragtime band' signified in an early 1910s context in which the term 'real jazz band' would not have conveyed anything to Australian patrons. Yet it is easy to imagine - and even accept — that this real ragtime music, played showily in the street parade or in the final chorus of Clarke's ragging as she competed with the band to get her audience jiggin', brought something excitingly different to Australian musical entertainment. This was probably something that was not heard again live until the end of Australia's Jazz Age, with the short and ill-fated visit of the black jazz band of the Colored Idea Company called, ironically, a Plantation Orchestra (Johnson, 2010).

The Hugo's Colored Minstrels tour essentially ended a three-and-a-halfdecade era in which African-American artists contributed directly to the shaping and content of popular music in Australia through their art and through what many white Australians artists learnt from them as collaborators, observers or students (Waterhouse, 1991, pp. 93-95). If we put aside the demeaning comic racial mocking inherent in minstrelsy as mainstream popular entertainment, it becomes possible to argue that Australia was, in fact, part of a 'good black music story'. However, after the Immigration Restriction Act 1901 was enacted to exclude 'coloured races' from gaining residency, an increasingly xenophobic Australian society discarded the opportunity to remain part of a story that could have enriched our popular music culture and our jazz scene in priceless ways. Even by the 1950s, the Musicians Union remained divided about removing Clause 1 of its constitutional objectives to 'uphold the White Australia policy, and prohibit the admission of coloured races' in deference to the musical contribution of black jazz greats (Webberley, 1952, p. 21). 
Abbott and Seroff (2002, p. 137) note:

More than one hundred black American entertainers witnessed the dawn of the twentieth century under Australasian skies, and among them were the cream of the vaudeville and minstrel stage. There were nearly as many first-rate black acts in Australia at this time as there were back in the States.

The constellation of major and minor black stars that orbited across the vista of Australian entertainment between the 1870s and World War One has already been recognised as a 'good black story' within Australian theatre studies. ${ }^{13}$ However, it has largely failed to catch the attention or interest of Australian jazz scholarship or, more surprisingly, the broader field of popular music studies. It is hoped that this initial musical investigation will encourage music scholarship that can penetrate the foggy gloom of white embarrassment about racial mocking and reveal a good black music story deserving of a rightful and dignified place in our popular music history.

\section{References}

Abbott, L. and D. Seroff. 2002. Out of Sight: The Rise of African American Popular Music, 1889-1895. Jackson: University Press of Mississippi.

——. 2007. Ragged but Right: Black Traveling Shows, 'Coon Songs,' and the Dark Pathway to Blues and Jazz. Jackson: University Press of Mississippi.

Albury Banner and Wodonga Express. 1912. 'Blacks Tabood'. 6 December, 20.

Bailly, L. 2009. Lacan: A Beginner's Guide. Oxford: Oneworld.

Berlin, E. A. 1980. Ragtime: A Musical and Cultural History. Berkeley: University of California Press.

Berresford, M. 2010. That's Got Em: The Life and Music of Wilbur Sweatman. Jackson: University Press of Mississippi. doi.org/10.14325/ mississippi/9781604730999.001.0001

13 For example, see entries on black minstrels in Australian Variety Theatre Archive at ozvta.com/ or Waterhouse (1991, pp. 61-97). 
Brisbane Courier. 1900. 'Entertainments'. 11 January, 2.

Brooks, T. 2004. Lost Sounds: Blacks and the Birth of the Recording Industry, 1890-1919. Urbana and Chicago: University of Illinois Press.

Burns, K. (Director) 2001. Jazz: A Film by Ken Burns. Florentine Films and WETA.

Critic. 1917. 'Trombone: Bands and Bandsmen'. 9 March, 6.

Daily Herald. 1912a. 'At the Theatre Royal'. 30 November, 2.

—_. 1912b. 'Hugo's Minstrels'. 30 November, 3.

Day, V. 1917. 'The Stage'. Referee. 25 July, 14.

Gennari, J. 2006. Blowin' Hot and Cool: Jazz and Its Critics. Chicago: University of Chicago Press. doi.org/10.7208/chicago/ 9780226289243.001 .0001

Gushee, L. 2005. Pioneers of Jazz: The Story of the Creole Band. New York: Oxford University Press.

Handy, W. C. 1970. Father of the Blues: An Autobiography. Edited by Arna Bontemps. New York: Collier Books.

Harney, B. 1897. Ben Harney's Rag Time Instructor. Chicago: Sol Bloom.

Johnson, B. 2010. 'Deportation Blues: Black Jazz and White Australia in the 1920s'. Journal for the International Society for the Study of Popular Music 1 (1): 1-13. doi.org/10.5429/2079-3871(2010)v1i1.5en

Keil, C. 1994. 'Participatory Discrepancies and the Power of Music'. In Music Grooves: Essays and Dialogues, edited by C. Keil and S. Feld, 96-108. Chicago: University of Chicago Press.

Launceston Examiner. 1877. 'Georgia Minstrels'. 11 September, 3.

Lewis, S. 2012. “'Untamed Music”: Early Jazz in Vaudeville'. Honours thesis, Florida State University. diginole.lib.fsu.edu/islandora/object/ fsu\%3A204554 (accessed 23 March 2016).

Londré, F. H. 2007. The Enchanted Years of the Stage: Kansas City at the Crossroads of American Theatre 1870-1930. Columbia: University of Missouri Press. 
Lotz, E. 1997. Black People: Entertainers of African Descent in Europe and Germany. Bonn, Germany: Birgit Lotz-Verlag.

Marquis, D. M. 2005. In Search of Buddy Bolden: First Man of Jazz. Rev. ed. Baton Rouge: Louisiana State University Press.

Newcastle Morning Herald and Miners' Advocate. 1876. 'Amusements'. 16 December, 5-6.

Pond, S. 2003. 'Jamming the Reception: Ken Burns, "Jazz", and the Problem of "America's Music"'. Quarterly Journal of the Music Library Association 60 (1): 11-45. doi.org/10.1353/not.2003.0124

Radano, R. 2003. Lying up a Nation: Race and Black Music. Chicago: University of Chicago Press.

Reiner, T. 2015. 'Approaching Music Through Language: A Lacanian Perspective'. Paper presented at the Symposium on Perspectives on Artistic Research in Music, Monash University, July.

South Australian Chronicle and Weekly Mail. 1877. 'The Georgia Minstrels'. 13 October, 15.

The Advertiser. 1918. 'The Majestic Theatre'. 19 August, 7.

The Cornwall Chronicle. 1877. 'The Georgia Minstrels'. 8 August, 2.

The Mail. 1912. 'Hugo's Minstrels'. 14 December, 3.

The Queenslander. 1888. 'Her Majesty's Opera House Hicks-Sawyer Minstrels'. 27 October, 752.

The Register. 1912. 'Amusements'. 16 December, 5.

Truth. 1912. 'Black Bucks and White Wantons'. 23 November, 5.

Waterhouse, R. 1991. From Minstrel Show to Vaudeville: the Australian Popular Stage 1788-1914. Kensington, NSW: New South Wales University Press.

Webberley, M. 1952. 'Notice of Motion to Hobart Branch of Musicians' Union of Australia'. Music Maker. August, 20.

Whitcomb, I. 1987. Irving Berlin and Ragtime America. London: Century Hutchinson. 
Whiteoak, J. 1994. “'Jazzing” and Australia's First Jazz Band'. Popular Music 13 (3): 279-295. doi.org/10.1017/S0261143000007200

—. 1999. Playing Ad Lib: Improvisatory Music in Australia, 1836-1970. Sydney: Currency Press.

—. 2001. 'Popular Music, Militarism, Women and the Early "Brass Band" in Australia'. Australasian Music Research 6: 27-48.

- 2014. "Demons of Discord Down Under: From "Jump Jim Crow" to "Australia’s First Jazz Band”' Jazz Research Journal 8 (1-2): 23-51.

Wirth, G. 1925. Round the World with a Circus: Memories of Trials and Tribulations. Melbourne: Troedel \& Cooper.

Wondrich, D. 2003. Stomp and Swerve: American Music Gets Hot, 18431924. Chicago: Chicago Review Press. 
This text is taken from Popular Music, Stars and Stardom, edited by Stephen Loy, Julie Rickwood and Samantha Bennett, published 2018 by ANU Press, The Australian National University, Canberra, Australia.

doi.org/10.22459/PMSS.06.2018.03 